\author{
(online) $=$ ISSN $2285-3642$ \\ ISSN-L = $2285-3642$ \\ Journal of Economic Development, Environment and People \\ Volume 4, Issue 3, 2015 \\ URL: http://jedep.spiruharet.ro \\ e-mail: office jedep@spiruharet.ro
}

\title{
Alternative forms for promotion and dissemination of good management practices
}

\author{
Elenko Zahariev ${ }^{1}$ \\ ${ }^{1}$ University of Agribusiness and Rural Development
}

\begin{abstract}
At the present stage actuality of the problem is predetermined by the needs of the real management practice in organizations and the need to offer theoretical and practical knowledge to enable it methodologically correct and methodically right to implement appropriate changes in the management of the particular organization.

The article is devoted to one aspect in the field of management - creating a new form of organization of management (called new favorite) - international managerial architecture. It argues that it was dictated by poor management of institutional and corporate level, the lack of adequate professional standards, control and monitoring of the activities of managers. An attempt is made to give a reasoned response to relatively basic question: "Predetermination or managerial obfuscation are alternative forms of promotion and dissemination of good management practices?". The goal is to answer the question in a relatively unbiased approach, insofar as possible minimizing subjectivity in the treatment of problems. Finally, certain results of the proposed thesis on the need for the creation of NIMA are discussed-structure and structural parameters. The discussions are based on the experience in the Republic of Bulgaria taken as an example situation.
\end{abstract}

Keywords: management, international management architecture, predetermination, obfuscation managerial, regulatory functions, institutionalization.

JEL Codes: J35, M11

\section{Introduction}

In the article the basic thesis involves creating a new form of organization management (called new favorite) - international managerial architecture (NIMA). This is no accident, nor it is a terminological obfuscation. Lynchpin for the new managerial architecture was dictated by poor management on institutional and corporate level, the lack of adequate professional standards, control and monitoring of the activities of managers. And here we will try to answer the main question - predetermination or managerial obfuscation are alternative forms of promotion and dissemination of best practices in management. The

\footnotetext{
${ }^{1}$ E-mail address: ezahariev@uard.bg
} 


\author{
(online) = ISSN $2285-3642$ \\ ISSN-L = 2285-3642 \\ Journal of Economic Development, Environment and People \\ Volume 4, Issue 3, 2015 \\ URL: $\underline{\text { http://jedep.spiruharet.ro }}$ \\ e-mail: office jedep@spiruharet.ro
}

justification for NIMA algorithm is guided by the principle that the placement of questions is the most direct way for their decision. In the case given the issues related to the organizational form of NIMA are: Why are causes of the crisis sought primarily in the subjective perspective and seen as a consequence of mercenary behavior? Can it be attributed to the NIMA to supervise and control managers, respectively the management team, and to perform regulatory functions? Is the system of indicators an important element for evaluation? and others. All this is the subject of this article.

\title{
2. New international management architecture: prerequisites and challenges
}

Prior to justify the thesis and related arguments, it is necessary to note that the financial and economic crisis is a result of the activities of management, managers respectively. For example, continuing with the old neoliberal postulates in the economy. Even in "glaring" indications inertia in the thinking of some "authorities" continues. Such is the case with the statement that "... culinary ethnic cleansing started in Italy is incomprehensible. This is a form of protectionism that will hardly keep old world trends"2. Simply, this means maintaining the status quo, regardless of accumulated negativity of such an approach. The fact is that the global economic crisis did not lead to a reassessment of the public reconstruction, personal participation in the system of capitalism, as some naively rushed to predict - body system heals the wounds, to prohibit drunk and late for work, to spend unnecessarily. As if the world will never be the same, but nothing has changed. The reasons are rooted in: scandals pension funds in the UK caused by drastic violations of shareholder rights, indiscriminate collapse and corporate fraud bankrupt "Enron" (USA, 2001), "Parmalat" (Italy, 2002), "Vivendi" (France, 2002), "Ahold" (Netherlands, 2003), the accounting firm "Anderson," the second-largest US telecommunications company "WorldCom". There begin to unravel statements and balance sheets and for the largest media conglomerate in the world "AOL Time Warner."

Incidentally, two centuries ago at the dawn of the American State, its chief ideologue Thomas Jefferson (third president of the USA) estimates that "banking elite is more dangerous than the regular army." A reflection of public discontent in the United States against skyscrapers corruption and peculiar internal "financial terrorism" was the created by the President new special team to investigate corporate fraud ${ }^{3}$. In connection with this, idea deserves attention that the internationalization and globalization of economies necessitates the adoption of principles and standards of corporate governance not only in individual countries but globally ${ }^{4}$.

Bulgaria did not also remain invariant with respect to the ongoing processes in the world. Along with the rapid growth and flooding the market with cheap money, justifiably speak of the so-called "Bubbles" grouped mainly in three segments - holiday homes, the price of land and the cost of the projects. Undoubtedly those bubble areas have proven to have been such because those are striking declines - the holiday homes of 1800 to EUR 200-300. Can we then talk about drama in the United States or Latvia where prices fell by $50 \%$, while in Bulgaria in the sea - with $500 \%$.

The foregoing gives rise to at least two conclusions. The first is that the situation in our country is not perfect and practically we should be waiting for very difficult times for the country as a whole and for the

\footnotetext{
${ }^{2}$ Damyanov, At. Eklektichni vazgledi za mezhdunarodniya biznes i menidzhmant. Narodnostopanski arhiv, kn. 1, 2009, p. 19.

${ }^{3}$ Zahariev, El. Korporativen menidzhmant. Svishtov: Tsenov, 2007, p. 9.

${ }^{4}$ Georgiev, Il. Korporativno upravlenie. Savremenen format. S: 2008 , p. 47-48.
} 


\author{
(online) $=$ ISSN $2285-3642$ \\ ISSN-L = $2285-3642$ \\ Journal of Economic Development, Environment and People \\ Volume 4, Issue 3, 2015 \\ URL: http://jedep.spiruharet.ro \\ e-mail: office jedep@spiruharet.ro
}

industry in particular. Being before an engine of growth in the country, the real estate sector has become the most risky industry. Banks limited funding, the market has become heavy and difficult. Reserves of many companies decreased dramatically.

The second conclusion is that the situation is further complicated by the fact that many companies do not maintain the liquidity and reasonable policies. Overall entrepreneurs do not have money, their markets shrank dramatically, and banks accept these as high-risk and do not finance them. Difficulties in the industry is already visible to the naked eye - barter began, rip off prices, etc. ${ }^{5}$.

It is a truism that if you do not help yourself, no one can help you. Otherwise, the situation is not getting worse but instead becomes hopeless. So, everything depends on the triad "state - society business". To go forward it is necessary public, politicians and business to agree priorities (as a precondition is the existence of a kind of social contract behind which stand parties, trade unions and employers) and those priorities to be followed regardless of who is in power. Serious chances for development are in: tourism, agriculture, logistics, financial centers on the Balkans. In the situation in which the world is at the moment, given the brutal response of Western governments to offshore areas, our country offers the lowest taxes in the EU. The Balkans is an area with potential yet to develop financial markets in Serbia, Albania, Macedonia. For this purpose, the Republic of Bulgaria can be positioned as a financial center on the Balkans.

Therefore, changes are necessary. Significantly, German Chancellor Merkel imposed limits in the opportunities to speculate on the stock exchange. That speculation led to the crisis. In major European countries state regulation of the economy have already been introduced (the idea is ripe in major European countries, as well as in the USA). The trend is more protectionism over the economy. To continue with the old neoliberal postulates is already inadmissible ${ }^{6}$. EU bank managers will receive bonuses not on projected profits, but only on realized. The creation of several institutions for financial supervision was approved. Among the most significant is the European Systemic Risk Board, which will forecast the dangers of the crisis in the EU, and suggests ways to overcome them.

In a study of three British scientists ${ }^{7}$ - David Staklar (University of Cambridge), Lawrence King (Oxford) and Professor. Martin McKee (London Institute of Health Hygiene and Tropical Medicine) concluded that privatization after the collapse of communism in 1989 has led to the deaths of at least 1.2 million people in Eastern Europe. Among the reasons for the high mortality stand following factors: mass unemployment and impoverishment; poor health ${ }^{8}$; stress; alcoholism and suicide, the main of them are alcoholism and psychological stress. "All of these problems, the authors conclude, were inevitable after the collapse of communism. West then offered franchise not for the traditional industrial capitalism but showed the

\footnotetext{
5 Usually crisis has three stages. The first is characterized by a decrease in prices, but there is still some profit (entrepreneurs in Bulgaria have already forgiven with their ideas for profit and learned that it is not $100 \%$ but $10 \%$ ). In the second stage entrepreneurs are ready to sell at cost, during the third stage - at loss.

${ }^{6}$ Not surprisingly, the thesis of "a qualitatively new kind of Keynesian policy" defined as a macroeconomic policy that stabilizes aggregate demand rather than encourage it, as in traditional Keynesianism, is defined as deserving attention.

${ }^{7}$ Shokova privatizatsiya sled 1989 g. ubiva pone 1,2 miliona choveka. For details: David Stukler, Lawrence King, Martin McKee. Mass privatisation and the post - communist mortality crisis: a cross - national analysis. www.thelancet.com Published Online January 15, 2009 DOI: 10.1016/So140-6736 (09) 60005-2.

${ }^{8}$ The cited study indicates that in Bulgaria every third prefers self to specialized consultation.
} 


\author{
(online) = ISSN $2285-3642$ \\ ISSN-L = 2285-3642 \\ Journal of Economic Development, Environment and People \\ Volume 4, Issue 3, 2015 \\ URL: $\underline{\text { http://jedep.spiruharet.ro }}$ \\ e-mail: office jedep@spiruharet.ro
}

neoliberal idea ${ }^{9}$ - anything that increases "wealth" - even at the cost of magic to inflate prices of real estate and other assets, is also as productive as building new industrial facilities and infrastructure. This new ideology has created a number of economies - balloons, which growth was solely based on debt financing inflation of real estate and the stock exchange". Here what capitalism was "planted". What else could be expected when for "overnight" artificially and hastily a "private property" has set up in which the capitalist class of entrepreneurs was not emerging over time, but suddenly and spontaneously, which could not bring the desired effect.

The problem with the design of the palette (categorization - anticipating, matching, delayed, number, requirements to meet, etc.) of economic indicators is not new. Its evolution has been clarified in the literature. The question now is: Is there and if so which indicators give us an idea of where the economy goes? Highly aggregated argument for a positive answer to the question is that the indicator that measures the state of the currency board is made of "Expat Compass"10 in Bulgaria and focuses mainly on course lev (Bulgarian currency) / euro. To be able to assess, there are being monitored 16 economic and political indicators grouped into four main groups: political issues - does government support the currency board? Does the Central Bank support it? Do European institutions support Bulgaria to join the ERM II and the Euro area?; budget and debt - budget balance, government expenditure, public debt, foreign liabilities of the private sector, fiscal reserves; issues related to the economic cycle - GDP growth, inflation, unemployment, health / stability of the banking system; external balances - current account deficit, trade deficit, foreign investment, tourism receipts, foreign exchange reserves.

Undoubtedly, the major requirements suggest that not always the indicator system can be second to none ${ }^{11}$. This necessitated the development and use of analytical indicators. They in turn represent different kinds of indexes displayed on a particular set of economic indicators. These are: free indexes, diffusion indices and indices of amplitude. Gradually from the 70s of XX century it has been establishing an international system of economic indicators with the efforts of the US, Japan, UK and Germany.

Changes are needed in the regulation of management by aligning the interests of the three levels of participation on international markets, respectively - the new global economy:

- official international state institutions;

- national governments and their regulatory authorities;

- international corporations directly involved in the functioning of international markets as a factor of economic growth.

In the short term priority is the creation of stable and sustainable NIMA which is able to neutralize any unlawful decisions and actions of managers at both the institutional and corporate level which is:

- timely and adequate supervision of the activities of institutional and corporate managers;

- addressing the shortcomings in the regulation of economic activity and the real economy as a whole by promoting transparency, stability and accountability flows (financial, monetary, etc.) in the information system of internationalization and globalization;

\footnotetext{
${ }^{9}$ The parameters of the neoliberal economic theory are in the chain: policy choice (rapid liberalization, fast privatization, economic stabilization) - recovery of enterprises - growth.

10 "Expat Compass" was created by "Expat Capital" - a financial company based in Sofia. It is issued once in two months in Bulgarian and English and it is distributed for free.

${ }^{11}$ Damyanov, At. Eklektichni vazgledi za mezhdunarodniya biznes i menidzhmant. Narodnostopanski arhiv, kn. 1, 2009, p. 11.
} 


\author{
(online) $=$ ISSN $2285-3642$ \\ ISSN-L = 2285-3642 \\ Journal of Economic Development, Environment and People \\ Volume 4, Issue 3, 2015 \\ URL: $\underline{\text { http://jedep.spiruharet.ro }}$ \\ e-mail: office jedep@spiruharet.ro
}

- establishing rules for supervision, accounting and protection of shareholders and consumers in the form of an international management rules covering adequately the multi-stakeholder and markets;

- launching an ambitious policy that will in the future can prevent management "ambitions" of wrongdoing ${ }^{12}$ to the detriment of shareholders and consumers of the country or corporation.

Industrial management in the XXI century is universal and the specifics of its implementation in Bulgaria are of paramount importance. It should be seen within the NIMA. Its peculiarities in Bulgaria are limited to:

- it is set as a mechanism for organizations to operate that reflects the phase of the life cycle of the national economy;

- it differs from traditional company management because of the role and specificities of the organizations as part of industrial policy;

- increased information asymmetry due to the opacity of the business (trade secret) and inadequate business intelligence;

- rules for industrial management are driven by a regulator in the face of the state (strong regulation of the economy distorts industrial management);

- unusual mechanism of industrial management because breach of general instructions, methods and strategies of NIMA;

- regulation of the industry changes industrial management in the national economy, which creates information asymmetry between domestic and foreign investors.

The only thing that can limit industrial managers do not make decisions and perform actions to the detriment of shareholders and society as a whole, including the receipt of bonuses based on projected or "hollow" results, it is the construction of NIMA, which regulates the "rules", i.e. what to do and what are the parameters that industrial managers can afford such as actions and costs. NIMA formulates rules and principles which must be followed by adequate mechanism for professional standards, preventive control and monitoring of industrial management, respectively the management of institutional and corporate level. The adoption of clearer and more consistent rules, principles, strategy and codes of behavior affects most directly the assessment of the future role of the NIMA and regulatory practice that is required by each country.

\title{
3. Approaches to NIMA
}

We will try to answer to the questions put into the introduction part as synthesized stick, speaking conditionally, to a relatively unbiased approach. Regarding the first question "Should NIMA be seen as a form of institutionalization or as a form of promotion of best practices in industrial management?" - in institutionalization there is a strict regulation - behavior, mandatory for its members, is set. This, at present, is hardly feasible for a variety of reasons, some of which are: the diversity of businesses (if you do a global framework, it will not be sufficiently complete and even for different businesses it could be controversial); resistance of managers and management teams (emphasizing that institutionalization is disadvantageous

\footnotetext{
${ }^{12}$ In the individual countries institutional board is needed, i.e. external supervision over industrial management, respectively industrial managers, till the new system of international law, principles, norms and standards set by the NIMA starts "working".
} 


\author{
(online) = ISSN $2285-3642$ \\ ISSN-L = $2285-3642$ \\ Journal of Economic Development, Environment and People \\ Volume 4, Issue 3, 2015 \\ URL: http://jedep.spiruharet.ro \\ e-mail: office jedep@spiruharet.ro
}

because it can lead to further bureaucracy and complexity of the management process in organizations, as well as disadvantageous positions in the framework regulation).

International management architecture is not an institution as familiar. From this perspective in the best case it can be considered as an advisory and expert body, working out recommendations for alternative forms of promotion and dissemination of best practices in industrial management. What an idea, which is a good solution in theory, some would say, but whether it can be successfully implemented in practice because usually best practices are rarely used and often circumvented, causing the opposite - bad practice. This can be avoided by compliance with a standard such as ISO, quality standards and management and leadership. The question is whether organizations are registered on it, if they follow it, and in case they are registered, whether they comply with the requirements. In order to have a successful introduction of a standard on industrial management, it must be comprehensive and binding for all, which in turn brings us back to institutionalization, i.e. the result is a vicious circle. And yet, the idea is worth.

The fore in response to the second question "Why are causes of the crisis sought primarily in a subjective term and they are seen as a result of mercenary behavior?" - intrudes assumption that if mercenary behavior ${ }^{13}$ is against the rules, it is not therefore the blame of the rules, but the opportunities that exist for breaking the rules. And if the rules are the best practices, their violation is an expression of bad management practices. Indeed, subjectivism leads people. Each individual sees himself/ herself first and then the other. From this perspective it can be assumed that individuals are guided by subjective judgments, seeking to satisfy their own needs, either through mercenary behavior. This requires as a prerequisite the revision of values, which, as mentioned previously, determines also the subjective view on things - what is good and what is bad. For example, "inflation" of bubbles in the economy is certainly good for managers because it meets their needs, but their desires for wealth and big bonuses, non-related to the product / service, is definitely not good from the perspective of society. A fact deserves attention that managers foresight in the background, i.e. priority is the current snapshot and not strategic thinking and behavior. This is most clearly evident in the crisis incubation period. But nothing lasts forever. Big bonuses cannot continue forever and, i.e. "hollow bonuses" or "hollow results," without results for shareholders and customers for their money. That is why the revision of the value system is an extremely important issue, and especially effective dissemination and enforcement of best practices among industrial management.

In this sense, the defended thesis is that the purpose of NIMA is to support best practices through their development and validation, and limit bad practices by developing mechanisms for timely diagnosis and prevention.

We understand that the crisis is a result of underestimation of risk, trade in stock markets and in bank lending. In this connection we assume that no desire to profit at any price, which is justified, but the passage of the reasonable amount of risk underlies the crisis. But what are the reasonable limits of risk? Especially fears of imminent risk of inflation in the world? In answering this question Joseph Stiglitz gives an example with the United States, stating that with the growth of US debt and fanning Fed today around the world arose concerns about future inflation. Prime Minister of China openly expressed the concerns about the future value of loans of about 1.5 billion dollars, which the country has provided the United States.

\footnotetext{
${ }^{13}$ It can not be denied that there would be no interest, let alone "self-interested", if exercised strict control to the extent necessary by the authorized authorities and institutions. Just let his lack lead in relation "manager - owner" is the economic interest and its essence- personal property. For details see: Zahariev, El. Diminuarea rolului statului in economia Bulgariei. Bucuresti, TRIBUNA ECONOMICA, 3/2000, pp. 69-71.
} 


\author{
(online) $=$ ISSN $2285-3642$ \\ ISSN-L = $2285-3642$ \\ Journal of Economic Development, Environment and People \\ Volume 4, Issue 3, 2015 \\ URL: http://jedep.spiruharet.ro \\ e-mail: office jedep@spiruharet.ro
}

None want to see the value of these assets reduced ${ }^{14}$. So that the crisis does not focus only on the collapse of the "Enron", "Parmalat" and the others mentioned above. Definitely it comes to crime. By the way, they will always be. At the heart of the crisis stands crisis in the theory, and hence the practice of management, including post-industrial management. In this aspect it can not be denied that NIMA is a good idea.

In answer to the third question "Can it be attributed to the NIMA to supervise and control managers, respectively the management team, and to perform regulatory functions?" - opponents seem at first to focus on the fact that NIMA is absurd to exercise any supervision and control of managers. So, according to some, further relates to the regulation. We will repeat again that it is committed to developing rules for conducting a successful policy in the economic life and in their promotion. We understand that any attempt to be assigned managerial, sanctions or any functions of direct intervention will make NIMA mission impossible. In this context, we believe that we must first, albeit fragmented, to outline policy principles, strategy and treatment standards issues.

Regarding the first point it should be noted that the main function of the state in managing the economy is the formation of an appropriate economic environment. In this context the principally reasonable question for this stage of development of our society arises about the ways and approaches to be followed in its implementation. What is meant? Assuming that science of management of national economy is in crisis, it should be pointed out that it is not as concentrated in management of organizations as in the sphere of state management of the economy. Hence the result - Bulgaria found itself in the category of least developed countries, since for decades the search for a solution to this problem in the country was founded on the dogma that all "power belongs to the market" and widespread liberalization. It is known that no underdeveloped countries exist, only mismanaged. And we proved that with the lack of even minimal supervision and control by authorized bodies on business, i.e. there is convincing evidence of the bankruptcy of their control center to supervise. It is hardly necessary to prove that it is driving on the track of events, but it should be the opposite.

The second point is directly related to the foregoing as its practical implementation requires the state economic policy to follow fundamental principles such as: the principle of self-organization of the national economy, the principle of minimum intervention, principle of equality and the liability relations, the principle of continuity and predictability of state economic policy, principle of minimum protection and the principle of unity of the economic environment ${ }^{15}$.

The scope of the strategy is the third point. In its construction priorities of the individual country should be considered, but according to the EU institutional framework. For example, in focusing the strategy on growth and employment (jobs) special attention should be paid to "greener" economic growth and development of human resources and, given the current economic crisis, the future strategy should work on consolidation of the financial sector and going out of crisis.

In the fourth point the fact should be borne in mind that globalization and the associated increase in interaction between countries and regions makes international standards extremely important. This applies with full force for NIMA. We believe that their development is an urgent need. From this viewpoint we argue that their construction should satisfy three basic principles. One is that the standards are

\footnotetext{
${ }^{14}$ Stiglits, Dzhouzef. Svobodno padane. Amerika, svetovnite pazari, krizata i vinovnite za neya. S: Info DAR, EOOD, 2010.

${ }^{15}$ For details: Zahariev, E. Predizvikatelstvata pred industrialniya menidzhmant - prioriteti i resheniya. Plovdiv: Talant, 2013, p. 384-386.
} 


\author{
(online) $=$ ISSN $2285-3642$ \\ ISSN-L = $2285-3642$ \\ Journal of Economic Development, Environment and People \\ Volume 4, Issue 3, 2015 \\ URL: http://jedep.spiruharet.ro \\ e-mail: office jedep@spiruharet.ro
}

recommendatory in nature, which ensures the ability of national governments to develop policies and state industrial management tailored to national circumstances and in the first place - their psychology. Another principle in the development of standards for NIMA and defining their scope is to take into account above all the needs and problems of "quality" of the existing institutional framework and the "competence" of its relevant components and their administrative capacity. The third principle is the dialogue with the community, working on projects aimed at achieving "sustainable to challenges" (political, economic, social, etc.) industrial management, regardless of its hierarchical status - international, regional or national.

With regard to the fourth question "Is the system of indicators an important element for evaluation?" it cannot be denied that the indicator system is an important tool for evaluation. At the same time we understand that the indicators as a tool should be applied depending on the value system that dominates in the relevant area. A consequence of this thesis is what we commented on values system-is it necessary to review it in the light of the determination what is good and what is bad? We believe that the state is one that must formulate and define priorities at institutional level, prioritizing needs, and therefore fulfills the necessary to their achievement regulatory functions deviations, and the vector of basic functions and tasks inherent in modern managers is on corporate level. In essence, such an approach in setting priorities means efficient use of all money of citizens and shareholders. It is consistent with the NIMA, which affects two points - corporate governance and competition policy in the context of liberalization and globalization. These include also new corporate culture and social responsibility and ethics of the organization.

The above really is a challenge worth, i.e. figuratively speaking of this "thorn" - analysis not only can come to a rabbit, but an elephant. For example, the problems of managing this means ${ }^{16}$ :

- Annual reporting - a guarantee to maintain reforms and collaborative communication.

- The grouping of countries that are facing or have dealt with similar challenges: a better focus on observation and control, enhancing profit from shared knowledge and exchange of good policies.

- Republic of Bulgaria holds the definition of pan-European objectives, and then specifying and determining the corresponding country-oriented purposes.

- General transparent and widely accepted by all member states a framework for evaluating progress is essential.

- Ensuring effective cooperation and participation of all stakeholders at all levels - responsibility of government.

- Strengthening the exchange and communication of successful reforms and examples of good practice at the lowest possible level that is closest to the people - a fact that sets the critical role of local and regional authorities.

Key issues for Bulgaria are: economic sustainability of public finances; new jobs in "green industries" and related infrastructure development; limiting inequality and poverty, reforms in education, health and pension system.

\title{
4. Conclusion
}

In conclusion it can be said that in today's increasing globalization, the importance of individual countries does not diminish, even those who are members of the EU but increase. The role of the nation grows, the more the basis of competition shifts to the creation and utilization of knowledge. Differences in

\footnotetext{
${ }^{16}$ For details: Konsultatsiya otnosno badeshtata strategiya „ES2020”: es.europa.eu/dgs/.../consultation_bg.htm.
} 


\author{
(online) $=$ ISSN $2285-3642$ \\ ISSN-L = $2285-3642$ \\ Journal of Economic Development, Environment and People \\ Volume 4, Issue 3, 2015 \\ URL: $\underline{\text { http://jedep.spiruharet.ro }}$ \\ e-mail: office jedep@spiruharet.ro
}

national values, culture, economic structure, institutions and history - all these factors have contributed to successfully enhance competitiveness. There are striking differences in the structure and patterns of competitiveness in each country. None country can and will be competitive in all or even in most sectors of the economy. Ultimately, countries achieve success in certain industries as the business environment in them is most promising, dynamic and stimulating by challenges. There is no doubt that the success of everything said here would not be the case without adequate support from the EU and the international community to make it possible to achieve the objectives and priorities considered, respectively accelerated construction of NIMA - a determining factor for the active participation of Bulgaria in increasing globalization. In this sense, Bulgarian industrial organizations, all structures on national and branch level should organize its activities in accordance with the policy principles, strategy and NIMA standards and good management practices to ensure effective national system of supervision and control of industrial management, respectively managers. On the other hand, Bulgaria should maintain an effective system of internal control functions, activities and management tasks in industrial organizations. For this purpose it is necessary to change many things, one of which is to strictly follow the basic management tools - strength, power, control. Not only in the face of the institutions, but also in the face of working organizations. And then, agreements, which ensure the pursuit of the fundamental parameters of the NIMA, and it as whole will really work.

\title{
5. References
}

[1] Damyanov, At. Eklektichni vazgledi za mezhdunarodniya biznes i menidzhmant. Narodnostopanski arhiv, kn. 1, 2009.

[2] Georgiev, II. Korporativno upravlenie. Savremenen format. S: 2008.

[3] Konsultatsiya otnosno badeshtata strategiya „ES2020”: es.europa.eu/dgs/.../consultation_bg.htm

[4] Shokova privatizatsiya sled 1989 g. ubiva pone 1,2 miliona choveka. For details: David Stukler, Lawrence King, Martin McKee. Mass privatisation and the post - communist mortality crisis: a cross - national analysis. www.thelancet.com Published Online January 15, 2009 DOI: 10.1016/So140-6736 (09) 60005-2.

[5] Stiglits, Dzhouzef. Svobodno padane. Amerika, svetovnite pazari, krizata i vinovnite za neya. S: Info DAR, EOOD, 2010.

[6] Zahariev, El. Diminuarea rolului statului in economia Bulgariei. Bucuresti, TRIBUNA ECONOMICA, 3/2000.

[7] Zahariev, El. Korporativen menidzhmant. Svishtov: Tsenov, 2007.

[8] Zahariev, El. Predizvikatelstvata pred industrialniya menidzhmant - prioriteti i resheniya. Plovdiv: Talant, 2013. 